factory histological examination; it should be done only when the result of radiological examination is equivocal.

A third of the patients in this series died, a clear indication of the serious potentialities of Hirschsprung's disease. That such a high mortality should be found in a series of patients in whom the disease had been recognized within the first month of life adds weight to the former estimates (Bodian et al., 1949 ; Eek and Knutrud, 1962) that $50 \%$ died in the first year of life.

The higher mortality in neonates has also been emphasized by Hofmann and Rehbein (1966): 15 of their 53 neonates died. They prefer to treat the condition by washouts and hot packs rather than by colostomy, to which they resorted only when conservative treatment failed. Only two of their patients died during conservative treatment and the remaining 22 survived subsequent resection of the aganglionic bowel. However, of the 31 in whom a colostomy had to be made, 8 died and 19 had a complicated course, and five more died subsequently after resection of the affected bowel.

It seems to us that when Hirschsprung's disease is diagnosed soon after birth the safest form of treatment is decompression of the obstructed bowel by a colostomy or ileostomy with as little delay as possible. Resection of the abnormally innervated segment of bowal should be delayed until the child is 1 year old or weighs $20 \mathrm{lb}$. (9.1 kg.).

It is not surprising that the mortality rate should be higher in the babies with the "long segment" type of disease, especially when the full extent of the lesion is not recognized at the first or subsequent operations to relieve the obstruction, and the colostomy or ileostomy is first made in aganglionic bowel.

In Hirschsprung's disease the term "abnormality of bowel habit" may imply either constipation or bouts of diarrhoea owing to the passage of faecal stained mucus round an impacted mass of faeces. In its most extreme form diarrhoea may be due to a sort of enterocolitis with mucosal ulceration and toxaemia that is often fatal. In another series of 47 patients with Hirschsprung's disease (Bill and Chapman, 1962) there were 24 with enterocolitis, of whom 21 were neonates and 8 died; though in this series enterocolitis did not occur after colostomy, it did in two of our patients (Cases 8 and 9). Bill and Chapman also found that patients who had once had enterocolitis were liable to its recurrence, especially after rectosigmoidectomy. Swenson and Davidson (1960) have reported a mortality rate of $33 \%$ in patients who were treated medically, but in those for whom a colostomy was made as soon as the disease was diagnosed the mortality rate was only $4 \%$. It seems that the best way to prevent enterocolitis may be to make a colostomy as soon as the diagnosis of Hirsch. sprung's disease is made, but it must be recognized that this does not always provide complete protection from enterocolitis or prevent death from it.

\section{Summary}

Of 54 babies suffering from Hirschsprung's disease who were admitted within a month of birth, $18(33 \%)$ died -5 of enterocolitis and 11 of other complications of the treatment; 2 mongols were not treated surgically.

The clinical disturbance associated with this form of congenital intestinal obstruction usually begins within the first two or three days after birth and is characterized by vomiting, abdominal distension, and abnormality of the bowel action. The clinical diagnosis was confirmed by $x$-ray examination after a barium enema in 24 out of 27 patients in this series; in one patient the appearances were equivocal and in two others the bowel had been washed out before the examination.

Neonatal intestinal obstruction due to Hirschsprung's disease should be relieved by a colostomy or ileostomy as soon as the diagnosis is established.

We are indebted to the late Mr. G. H. Macnab, Mr. D. J. Waterston, and Mr. H. H. Nixon for allowing us to include patients under their care in this survey.

\section{REFERENCES}

Bill, A. H., jun., and Chapman, N. D. (1962). Amer. F. Surg., 103, 70 Bodian, M., and Carter, C. O. (1963). Ann. hum. Genet., 26, 261. Stephens, F. D., and Ward, B. C. H. (1949). Lancet, 1, 6. Eek, S and Knutrud, O (1962) f. Oslo Cy Hosp. 12, 245.

Forshail, I. (1964). Ұ. roy. Coll. Surg. Edinb., 10, 31.

Hofhann, S and Rehbein. Fo (i966). Zbl. Kinderchir., 3, 182. Holmann, D., and Eckstein, H. B., and Nixon, H. H. (1965). Amer. ₹. Dis. Child., 109, 101.

Swenson, O., and Bili, A. H., jun. (1948). Surgery, 24, 212.

and Davidson, F. Z. (1960). New Engl. F. Med., 262, 64.

Waterston, D. J., Bonham-Carter, R. E., and Aberdeen, E. (1963) Lancet, 2, 55 .

Wyllie, G. G. (1957). Ibid., 1, 850.

Young, D. G., and Wilkinson, A. W. (1966). Ibid., 2, 18.

\title{
Overinflation of the Lungs in Coal Miners
}

\author{
COLIN OGILVIE, ${ }^{*}$ M.D., M.R.C.P. ; KEITH BROWN, $\dagger$ M.D., M.R.C.P. ; W. E. KEARNS, $\ddagger$ M.B., CH.B.
}

Brit. med. F., 1967, 3, 10-14

Coal miners whose chest radiographs are normal tend to be more breathless than non-miners of the same age group, but a pattern of dysfunction distinct from chronic non-industrial lung disease has not been observed.

The purpose of this report is to compare the results of lungfunction tests in coal miners referred to a physiological laboratory because of unexplained dyspnoea with those obtained in a group of men suffering from chronic non-specific lung disease.

\section{Patients}

The first group consists of 17 miners (two from Yorkshire and 15 from West Lancashire coal fields) who were referred during 1963-6 to a lung-function laboratory providing a routine service for the region. In each case the miner had been referred by a consultant physician because physical and radiological examination had failed to reveal an adequate cause for his disability. These 17 cases represent the total number of miners referred to the laboratory in this way. Apart from clinical or radiological signs compatible with either chronic non-specific lung disease or pneumoconiosis, no cardiac or pulmonary cause for dyspnoea could be found in any of these patients. The only miners attending the laboratory during 1963-6 and excluded from this report were those referred for routine preoperative assessment or for the investigation of a disease not directly related to their occupation (mitral stenosis, bronchiectasis, bronchial carcinoma, or tuberculosis).

* Consultant Physician.

† Senior Medical Registrar.

$\ddagger$ Medical Registrar.

Regional Cardiothoracic Centre, Broadgreen Hospital, Liverpool 14. 
The occupational history and the clinical and radiological findings for the 17 miners are recorded in Table $I$. The average age was 57 years at the time of the investigation. Only five of the miners were still working underground, the remainder having left the mines an average of five years previously. The average duration of underground work was 32 years, 12 of the 17 miners having worked underground for 30 or more years. Of the five with less than 30 years underground, two had worked in other dusty occupations (26 years in a lead mine and seven years in a granite quarry respectively). The 17 miners all complained of either moderate (grade 2) or severe (grade 3) dyspnoea on effort (see Methods). The average duration of effort dyspnoea was six years. Five miners denied having any cough, while 12 complained of cough with a variable amount of sputum. Most of them stated that cough and dyspnoea started together, but none was sure about the total duration of cough.

TABLE I.-Occupational and Clinical History and Radiographic Findings in Group 1 (Coal Miners)

\begin{tabular}{|c|c|c|c|c|c|c|}
\hline $\begin{array}{l}\text { Case } \\
\text { No. }\end{array}$ & $\begin{array}{l}\text { Years } \\
\text { Under- } \\
\text { ground }\end{array}$ & $\begin{array}{c}\text { Years } \\
\text { Since } \\
\text { Leaving } \\
\text { Mines }\end{array}$ & Symptoms & $\begin{array}{c}\text { Grade } \\
\text { of } \\
\text { Dys- } \\
\text { pnoea }\end{array}$ & $\begin{array}{l}\text { Signs of } \\
\text { Bronchitis }\end{array}$ & $\begin{array}{c}\begin{array}{c}X \text {-ray } \\
\text { Evidence } \\
\text { of } \\
\text { Pneumo- } \\
\text { coniosis }\end{array}\end{array}$ \\
\hline 1 & 38 & 4 & $\begin{array}{l}\text { Cough and effort } \\
\text { dyspnoea } 5 \text { years }\end{array}$ & 3 & $\begin{array}{l}\text { Wheeze on } \\
\text { forced }\end{array}$ & None \\
\hline 2 & 38 & 7 & $\begin{array}{l}\text { Effort dyspnoea } 6 \\
\text { years. No cough }\end{array}$ & 2 & None & Category \\
\hline 3 & $6^{*}$ & 8 & Efort dyspnoea 10 & 2 & $"$ & ", \\
\hline $4^{\circ}$ & 45 & 2 & $\begin{array}{l}\text { Cough and effort } \\
\text { dyspnoea } 5 \text { years }\end{array}$ & 2 & $"$ & " \\
\hline 5 & 33 & 4 & $\begin{array}{c}\text { Cough and effort } \\
\text { dyspnoea } 4 \text { years }\end{array}$ & 2 & $\begin{array}{c}\text { Coarse basal } \\
\text { crepitations }\end{array}$ & ," \\
\hline 6 & 35 & 9 & $\begin{array}{l}\text { Cough and effort } \\
\text { dyspnoea } 9 \text { years }\end{array}$ & 3 & $\begin{array}{l}\text { Wheeze on } \\
\text { forced } \\
\text { expiration }\end{array}$ & None \\
\hline 7 & 30 & 10 & $\begin{array}{l}\text { Cough and effort } \\
\text { dyspnoea } \\
12 \text { years }\end{array}$ & 3 & $\begin{array}{c}\text { Generalized } \\
\text { expiratory } \\
\text { wheezing }\end{array}$ & " \\
\hline 8 & $6+$ & 25 & $\begin{array}{l}\text { Effort dyspnoea } 2 \\
\text { years. No cough }\end{array}$ & 2 & None & ". \\
\hline 9 & 51 & 0 & $\begin{array}{l}\text { Effort dyspnoea } 8 \\
\text { years. No cough }\end{array}$ & 3 & $"$ & ". \\
\hline 10 & 50 & 0 & $\begin{array}{l}\text { Cough and effort } \\
\text { dyspnoea } 1 \text { year }\end{array}$ & 2 & $"$ & ,. \\
\hline 11 & 17 & 8 & $\begin{array}{l}\text { Effort dyspnoea } \\
\text { ? duration. No } \\
\text { cough }\end{array}$ & 3 & $\begin{array}{c}\text { Coarse basal } \\
\text { crepitations }\end{array}$ & " \\
\hline 12 & 24 & 11 & $\begin{array}{l}\text { Cough and effort } \\
\text { dyspnoea } \\
15 \text { years }\end{array}$ & 3 & $\begin{array}{l}\text { Wheeze on } \\
\text { forced } \\
\text { expiration }\end{array}$ & ". \\
\hline 13 & 31 & 0 & $\begin{array}{l}\text { Cough } 5 \text { years. } \\
\text { Eftort dyspnoea } \\
1 \text { year }\end{array}$ & 2 & None & Category 1 \\
\hline 14 & 27 & $"$ & $\begin{array}{l}\text { Cough and effort } \\
\text { dyspnoea } \\
6 \text { months }\end{array}$ & 2 & , & " \\
\hline 15 & 35 & 2 & $\begin{array}{l}\text { Effort dyspnoea } 19 \\
\text { years. Cough } \\
1 \text { year }\end{array}$ & 3 & - & None \\
\hline 16 & 42 & 1 & $\begin{array}{l}\text { Cough } 2 \text { years. } \\
\text { Effort dyspnoea } \\
1 \text { year }\end{array}$ & 2 & & Category 1 \\
\hline 17 & 30 & ) & $\begin{array}{l}\text { Cough } 1 \text { year. } \\
\text { Effort dyspnoea } \\
6 \text { months } \\
\end{array}$ & 2 & $\begin{array}{l}\text { Wheeze on } \\
\text { forced } \\
\text { expiration }\end{array}$ & " \\
\hline Mean & 32 & 5 & & & & \\
\hline
\end{tabular}

Plus 26 years in lead mines.
Physical signs of bronchitis were present in seven: expiratory wheeze was evident in five and coarse basal crepitations without wheeze in two others. The chest radiographs showed evidence of simple pneumoconiosis (categories 1-3) in eight cases and were clear in the remaining nine.

The second group consists of 15 male non-miners aged 50 and over referred to the laboratory as cases of chronic bronchitis and/or emphysema. These patients fulfilled the criteria required for a diagnosis of chronic non-specific lung disease: they were all suffering from chronic cough with sputum and/or persistent breathlessness not associated with localized lung disease of any kind, generalized specific infective diseases of the lungs, pneumoconiosis, generalized pulmonary fibrosis or granulomata, primary cardiovascular or renal disease, diseases of the chest wall, anaemia, or psychoneurosis (Ciba Guest Symposium, 1959). The 15 patients represent the total number of males aged 50 and over with chronic non-specific lung disease for whom adequate physiological data were available in the laboratory records.

\section{Methods}

The physiological techniques used are those described in previous publications (Ogilvie et al., 1963), and include: (1) the subdivisions of the lung volume, including vital capacity (V.C.), functional residual capacity (F.R.C.), and residual volume (R.V.). F.R.C. and R.V. were measured by means of a closed-circuit helium method; (2) maximum voluntary ventilation at 80 respirations per minute (M.V.V.80); (3) maximum inspiratory and expiratory flow rates derived from the forced spirogram (M.I.F.R. and M.E.F.R.) ; (4) the forced expiratory volume in 1 second (F.E.V..$\left._{1}\right)$; (5) arterial $\mathrm{CO}_{2}$ tension by the rebreathing method $\left(\mathrm{PCO}_{2}\right)$; and (6) transfer factor for carbon monoxide (diffusing capacity, $\mathrm{DL}$ ) by the single-breath technique.

The degree of dyspnoea was recorded for each miner before the physiological tests were carried out, according to the following grading:

Grade 1 (mild). Dyspnoea only on severe exertion such as running on the level or hurrying upstairs.

Grade 2 (moderate). Dyspnoea on one flight of stairs or walking up inclines. No dyspnoea when walking at a normal pace on level ground.

Grade 3 (severe). Dyspnoea when walking at a normal pace on level ground.

The normal values for lung volumes were predicted from the formula of Baldwin et al. (1948). The normal values for transfer factor were predicted from the formula of Ogilvie et al. (1957). The results in the two groups were also compared with those obtained in five normal men aged 50 and over studied in the same laboratory. These five men had been referred to general surgical clinics of the hospital from the same area as the

TABLE II.-Physiological Findings in Group 1 (Coal Miners)

\begin{tabular}{|c|c|c|c|c|c|c|c|c|c|c|c|c|c|c|c|c|c|}
\hline \multirow{2}{*}{$\begin{array}{l}\text { Case } \\
\text { No. }\end{array}$} & \multirow{2}{*}{ Age } & \multicolumn{2}{|c|}{ Height } & \multicolumn{2}{|c|}{ Weight } & \multirow{2}{*}{ v.i.) } & \multirow{2}{*}{$\underset{\text { (1.) }}{\text { F.R.C. }}$} & \multirow{2}{*}{ R.V. } & \multirow{2}{*}{ T.L.C. } & \multirow{2}{*}{$\frac{\text { R.V. }}{\text { T.L.C. } \%}$} & \multirow{2}{*}{ (1./min.) } & \multirow{2}{*}{$\underset{\text { F.E.V. }}{\text { F.C. }} \%$} & \multirow{2}{*}{$\underset{\text { (1./min.) }}{\text { M.I.F.R. }}$} & \multirow{2}{*}{$\begin{array}{l}\text { M.E.F.R. } \\
\text { (1./min.) }\end{array}$} & \multirow{2}{*}{$\begin{array}{l}\text { M.I.F.R. } \\
\text { M.E.F.R. }\end{array}$} & \multirow{2}{*}{$\begin{array}{c}\text { Trans- } \\
\text { fer } \\
\text { Factor } \\
(\% \\
\text { Normal }\end{array}$} & \multirow{2}{*}{$\begin{array}{l}\mathrm{PcO}_{3} \\
(\mathrm{~mm} . \\
\mathrm{Hg})\end{array}$} \\
\hline & & in. & $\mathrm{cm}$. & lb. & kg. & & & & & & & & & & & & \\
\hline $\begin{array}{r}1 \\
2 \\
3 \\
4 \\
5 \\
6 \\
7 \\
8 \\
9 \\
10 \\
11 \\
12 \\
13 \\
14 \\
15 \\
16 \\
17\end{array}$ & $\begin{array}{l}59 \\
55 \\
58 \\
61 \\
52 \\
63 \\
54 \\
66 \\
65 \\
64 \\
65 \\
55 \\
45 \\
41 \\
61 \\
60 \\
52\end{array}$ & $\begin{array}{l}70 \\
70 \\
68 \\
66 \\
72 \\
67 \\
69 \\
69 \\
65 \\
70 \\
64 \\
69 \\
69 \\
68 \\
63 \\
64 \\
66\end{array}$ & $\begin{array}{l}178 \\
178 \\
172 \\
168 \\
183 \\
170 \\
175 \\
175 \\
165 \\
178 \\
163 \\
175 \\
175 \\
172 \\
160 \\
163 \\
168\end{array}$ & $\begin{array}{l}173 \\
145 \\
168 \\
178 \\
165 \\
171 \\
182 \\
140 \\
135 \\
143 \\
106 \\
136 \\
154 \\
143 \\
113 \\
148 \\
165\end{array}$ & $\begin{array}{l}78.4 \\
65.7 \\
76.2 \\
80.7 \\
74.8 \\
77.5 \\
82.5 \\
63.5 \\
61.2 \\
64.8 \\
48.0 \\
61.6 \\
69.8 \\
64.8 \\
51.2 \\
67.1 \\
74.8 \\
\end{array}$ & $\begin{array}{l}3.2 \\
3.1 \\
3.7 \\
2.1 \\
3.7 \\
1.7 \\
1.5 \\
4.3 \\
2.2 \\
3.7 \\
1.6 \\
2.9 \\
3.5 \\
3.4 \\
2.4 \\
1.7 \\
3.5\end{array}$ & $\begin{array}{l}5 \cdot 0 \\
3.8 \\
4.7 \\
4 \cdot 5 \\
5 \cdot 1 \\
4 \cdot 0 \\
6 \cdot 1 \\
6 \cdot 7 \\
6 \cdot 4 \\
5 \cdot 2 \\
6.3 \\
6 \cdot 3 \\
4 \cdot 0 \\
3.1 \\
4 \cdot 0 \\
3.3 \\
4 \cdot 2\end{array}$ & $\begin{array}{l}4.6 \\
3.1 \\
3.4 \\
3.4 \\
3.9 \\
3.8 \\
5.7 \\
5.2 \\
5.9 \\
3.8 \\
5.3 \\
5.0 \\
3.3 \\
2.8 \\
3.5 \\
3.1 \\
3.1\end{array}$ & $\begin{array}{l}7.8 \\
6.2 \\
7.2 \\
5.5 \\
7.5 \\
5.5 \\
7.2 \\
9.5 \\
8.1 \\
7.4 \\
6.9 \\
7.9 \\
6.8 \\
6.2 \\
5.9 \\
4.8 \\
6.6\end{array}$ & $\begin{array}{l}60 \\
50 \\
49 \\
62 \\
52 \\
70 \\
79 \\
55 \\
74 \\
51 \\
77 \\
63 \\
48 \\
45 \\
60 \\
65 \\
46 \\
\end{array}$ & $\begin{array}{l}50 \\
72 \\
80 \\
72 \\
99 \\
44 \\
24 \\
80 \\
30 \\
98 \\
34 \\
44 \\
84 \\
82 \\
50 \\
60 \\
86 \\
\end{array}$ & $\begin{array}{l}41 \\
68 \\
56 \\
71 \\
53 \\
67 \\
51 \\
68 \\
52 \\
60 \\
40 \\
36 \\
55 \\
60 \\
52 \\
70 \\
70 \\
\end{array}$ & $\begin{array}{r}150 \\
120 \\
150 \\
172 \\
50 \\
120 \\
200 \\
171 \\
150 \\
150 \\
120 \\
200 \\
86 \\
67 \\
120 \\
\end{array}$ & $\begin{array}{r}100 \\
240 \\
120 \\
172 \\
46 \\
32 \\
300 \\
50 \\
300 \\
-55 \\
200 \\
400 \\
120 \\
100 \\
120 \\
\end{array}$ & $\begin{array}{l}1.5 \\
0.5 \\
1.2 \\
1.0 \\
1.1 \\
3.7 \\
0.7 \\
3.4 \\
0.5 \\
-1.7 \\
0.7 \\
0.5 \\
0.7 \\
0.7 \\
1.0\end{array}$ & $\begin{array}{r}108 \\
82 \\
105 \\
85 \\
93 \\
120 \\
82 \\
112 \\
113 \\
93 \\
67 \\
62 \\
102 \\
120 \\
103 \\
130\end{array}$ & $\begin{array}{l}33 \\
40 \\
29 \\
28 \\
49 \\
38 \\
= \\
= \\
34 \\
\cdots \\
= \\
= \\
=\end{array}$ \\
\hline Mean & 57 & 67 & 170 & 151 & $68 \cdot 4$ & 2.8 & 5.0 & $4 \cdot 1$ & 6.9 & 60 & 65 & 57 & 142 & 164 & 1.3 & 99 & 36 \\
\hline
\end{tabular}


TABLE III.-Physiological Findings in Group 2 (Chronic Non-specific Lung Disease)

\begin{tabular}{|c|c|c|c|c|c|c|c|c|c|c|c|c|c|c|c|c|c|}
\hline \multirow{2}{*}{$\begin{array}{l}\text { Case } \\
\text { No. }\end{array}$} & \multirow{2}{*}{ Age } & \multicolumn{2}{|c|}{ Height } & \multicolumn{2}{|c|}{ Weight } & \multirow{2}{*}{$\begin{array}{l}\text { v.c. } \\
\text { (i.) }\end{array}$} & \multirow{2}{*}{$\underset{\text { (1.) }}{\text { F.R.C. }}$} & \multirow{2}{*}{$\begin{array}{l}\text { R.V. } \\
\text { (1.) }\end{array}$} & \multirow{2}{*}{ T.L.C. } & \multirow{2}{*}{$\frac{\text { R.V. }}{\text { T.L.C. }} \%$} & \multirow{2}{*}{$\begin{array}{l}\text { M.V.V.V. } \\
\text { (1./min.) }\end{array}$} & \multirow{2}{*}{$\frac{\text { P.E.V.1 }}{\text { V.C. }} \%$} & \multirow{2}{*}{$\underset{\text { (1./min.) }}{\text { M.I.F.R. }}$} & \multirow{2}{*}{$\underset{(1 . / \mathrm{min} .)}{\text { M.R.F.R. }}$} & \multirow{2}{*}{$\frac{\text { M.I.F.R. }}{\text { M.E.F.R. }}$} & \multirow{2}{*}{$\begin{array}{c}\text { Trans- } \\
\text { fer } \\
\text { Factor } \\
(\% \\
\text { Normal) }\end{array}$} & \multirow{2}{*}{$\begin{array}{l}\text { Pcon } \\
(\mathrm{mm} \\
\mathbf{H g})\end{array}$} \\
\hline & & in. & $\mathrm{cm}$. & lb. & kg. & & & & & & & & & & & & \\
\hline $\begin{array}{r}1 \\
2 \\
3 \\
4 \\
5 \\
6 \\
7 \\
8 \\
89 \\
10 \\
11 \\
12 \\
13 \\
14 \\
15\end{array}$ & $\begin{array}{l}50 \\
59 \\
56 \\
53 \\
56 \\
55 \\
57 \\
61 \\
67 \\
62 \\
62 \\
70 \\
51 \\
59 \\
56\end{array}$ & $\begin{array}{l}68 \\
63 \\
65 \\
68 \\
65 \\
68 \\
68 \\
68 \\
67 \\
67 \\
67 \\
69 \\
69 \\
65 \\
69\end{array}$ & $\begin{array}{l}172 \\
160 \\
165 \\
172 \\
165 \\
172 \\
172 \\
172 \\
170 \\
170 \\
170 \\
175 \\
175 \\
165 \\
175\end{array}$ & $\begin{array}{l}187 \\
128 \\
145 \\
154 \\
157 \\
122 \\
143 \\
147 \\
125 \\
115 \\
135 \\
126 \\
143 \\
109 \\
175\end{array}$ & $\begin{array}{l}84 \cdot 8 \\
58 \cdot 0 \\
65.7 \\
69.8 \\
71.2 \\
55 \cdot 3 \\
64 \cdot 8 \\
66.6 \\
56 \cdot 6 \\
52.1 \\
61.2 \\
57.1 \\
64.8 \\
49.4 \\
79 \cdot 3\end{array}$ & $\begin{array}{l}1.8 \\
1.8 \\
2.2 \\
1.9 \\
1.7 \\
2.4 \\
3.0 \\
1.99 \\
1.8 \\
2.2 \\
2.6 \\
2.8 \\
2.6 \\
2.6 \\
2.8\end{array}$ & $\begin{array}{l}3.9 \\
3.0 \\
6.1 \\
3.9 \\
5.9 \\
6.3 \\
4.9 \\
2.9 \\
4.8 \\
5.0 \\
5.1 \\
4.6 \\
6.8 \\
4.4 \\
3.5\end{array}$ & $\begin{array}{l}3 \cdot 5 \\
2 \cdot 7 \\
5 \cdot 4 \\
3 \cdot 2 \\
5 \cdot 6 \\
5 \cdot 4 \\
4 \cdot 3 \\
2 \cdot 6 \\
4 \cdot 5 \\
4 \cdot 4 \\
4 \cdot 1 \\
3 \cdot 8 \\
6 \cdot 2 . \\
3 \cdot 0 \\
2 \cdot 7\end{array}$ & $\begin{array}{l}5.3 \\
4.5 \\
7.6 \\
5.1 \\
7.3 \\
7.8 \\
7.3 \\
4.5 \\
6.3 \\
6.6 \\
6.7 \\
6.6 \\
8.8 \\
5.6 \\
5.5\end{array}$ & $\begin{array}{l}66 \\
60 \\
71 \\
63 \\
76 \\
70 \\
59 \\
58 \\
72 \\
67 \\
61 \\
57 \\
70 \\
54 \\
49\end{array}$ & $\begin{array}{l}21 \\
36 \\
30 \\
26 \\
24 \\
26 \\
52 \\
45 \\
26 \\
38 \\
40 \\
38 \\
40 \\
38 \\
24\end{array}$ & $\begin{array}{l}30 \\
52 \\
36 \\
37 \\
38 \\
28 \\
40 \\
48 \\
37 \\
46 \\
42 \\
36 \\
41 \\
39 \\
20\end{array}$ & $\begin{array}{r}150 \\
150 \\
194 \\
97 \\
154 \\
167 \\
150 \\
150 \\
100 \\
187 \\
162 \\
193 \\
143 \\
92 \\
130\end{array}$ & $\begin{array}{l}12 \\
80 \\
30 \\
21 \\
26 \\
17 \\
75 \\
35 \\
10 \\
33 \\
58 \\
40 \\
30 \\
36 \\
27\end{array}$ & $\begin{array}{r}12.5 \\
1.9 \\
6.5 \\
4.6 \\
5.9 \\
9.8 \\
2.0 \\
4.3 \\
10.0 \\
5.7 \\
2.9 \\
4.8 \\
4.7 \\
2.6 \\
4.8\end{array}$ & $\begin{array}{c}86 \\
90 \\
78 \\
38 \\
74 \\
55 \\
29 \\
65 \\
10 \\
7 \\
29 \\
9 \\
17 \\
33 \\
13\end{array}$ & $\begin{array}{l}64 \\
50 \\
= \\
= \\
\overline{41} \\
37 \\
43 \\
\frac{32}{32} \\
= \\
\overline{31}\end{array}$ \\
\hline Mean & 58 & 67 & 170 & 141 & 63.9 & $2 \cdot 3$ & $5 \cdot 4$ & $4 \cdot 1$ & $6 \cdot 4$ & 63 & 34 & 39 & 148 & 35 & 5.5 & 42 & 43 \\
\hline
\end{tabular}

TABLe IV.-Physiological Findings in Five Normal Men

\begin{tabular}{|c|c|c|c|c|c|c|c|c|c|c|c|c|c|c|c|c|}
\hline \multirow{2}{*}{$\begin{array}{l}\text { Case } \\
\text { No. }\end{array}$} & \multirow{2}{*}{ Age } & \multicolumn{2}{|c|}{ Height } & \multicolumn{2}{|c|}{ Weight } & \multirow{2}{*}{ v.C. } & \multirow{2}{*}{$\underset{(1 .)}{\text { F.R.C. }}$} & \multirow{2}{*}{ R.V. } & \multirow{2}{*}{ T.L.C. } & \multirow{2}{*}{$\frac{\text { R.V. }}{\text { T.L.C. }} \%$} & \multirow{2}{*}{ M.V.V. } & \multirow{2}{*}{$\frac{\text { F.E.V.'. }}{\text { V.C. }} \%$} & \multirow{2}{*}{ M.I.F.R. } & \multirow{2}{*}{ M.E.F.R. } & \multirow{2}{*}{$\frac{\text { M.I.F.R. }}{\text { M.E.F.R. }}$} & \multirow{2}{*}{$\begin{array}{c}\text { Transfer } \\
\text { Factor } \\
\text { (\% } \\
\text { Normal) }\end{array}$} \\
\hline & & in. & cm. & lb. & kg. & & & & & & & & & & & \\
\hline $\begin{array}{l}1 \\
2 \\
3 \\
4 \\
5\end{array}$ & $\begin{array}{l}55 \\
58 \\
69 \\
50 \\
50 \\
\end{array}$ & $\begin{array}{l}68 \\
69 \\
67 \\
65 \\
69 \\
\end{array}$ & $\begin{array}{l}172 \\
175 \\
170 \\
165 \\
175 \\
\end{array}$ & $\begin{array}{l}168 \\
162 \\
168 \\
135 \\
123 \\
\end{array}$ & $\begin{array}{l}76 \cdot 2 \\
73 \cdot 4 \\
76 \cdot 2 \\
61 \cdot 2 \\
55 \cdot 7 \\
\end{array}$ & $\begin{array}{l}3.3 \\
3.9 \\
3.7 \\
3.7 \\
3.4 \\
\end{array}$ & $\begin{array}{l}2.5 \\
2.3 \\
2.3 \\
3.3 \\
2.8\end{array}$ & $\begin{array}{l}2.2 \\
1.0 \\
1.8 \\
2.1 \\
1.6 \\
\end{array}$ & $\begin{array}{l}5.5 \\
4.9 \\
5.5 \\
5.8 \\
5.0\end{array}$ & $\begin{array}{l}42 \\
21 \\
33 \\
36 \\
32\end{array}$ & $\begin{array}{r}95 \\
60 \\
90 \\
108 \\
77\end{array}$ & $\begin{array}{l}76 \\
62 \\
66 \\
74 \\
65\end{array}$ & $\begin{array}{l}240 \\
200 \\
170 \\
200 \\
200\end{array}$ & $\begin{array}{l}400 \\
240 \\
300 \\
300 \\
300\end{array}$ & $\begin{array}{l}0.6 \\
0.8 \\
0.6 \\
0.7 \\
0.7\end{array}$ & $\begin{array}{r}107 \\
73 \\
94 \\
95 \\
76 \\
\end{array}$ \\
\hline Iean & 57 & 68 & 172 & 151 & $68 \cdot 4$ & 3.6 & $2 \cdot 6$ & 1.7 & $5 \cdot 3$ & 33 & 86 & 69 & 202 & 308 & 0.7 & 90 \\
\hline
\end{tabular}
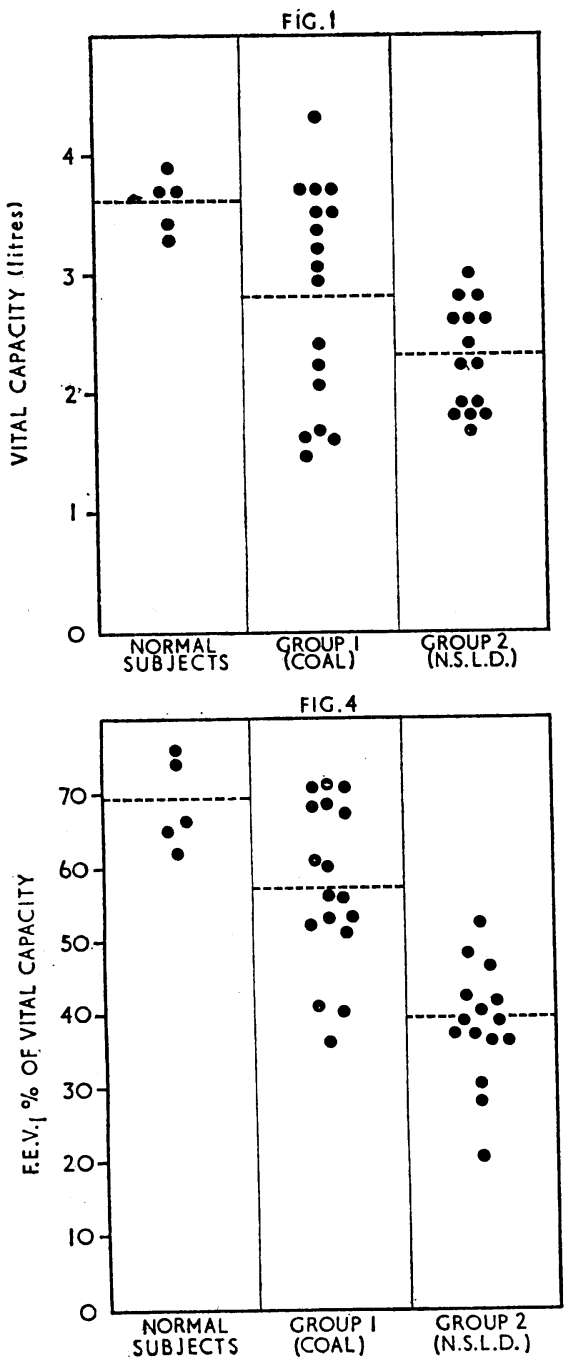
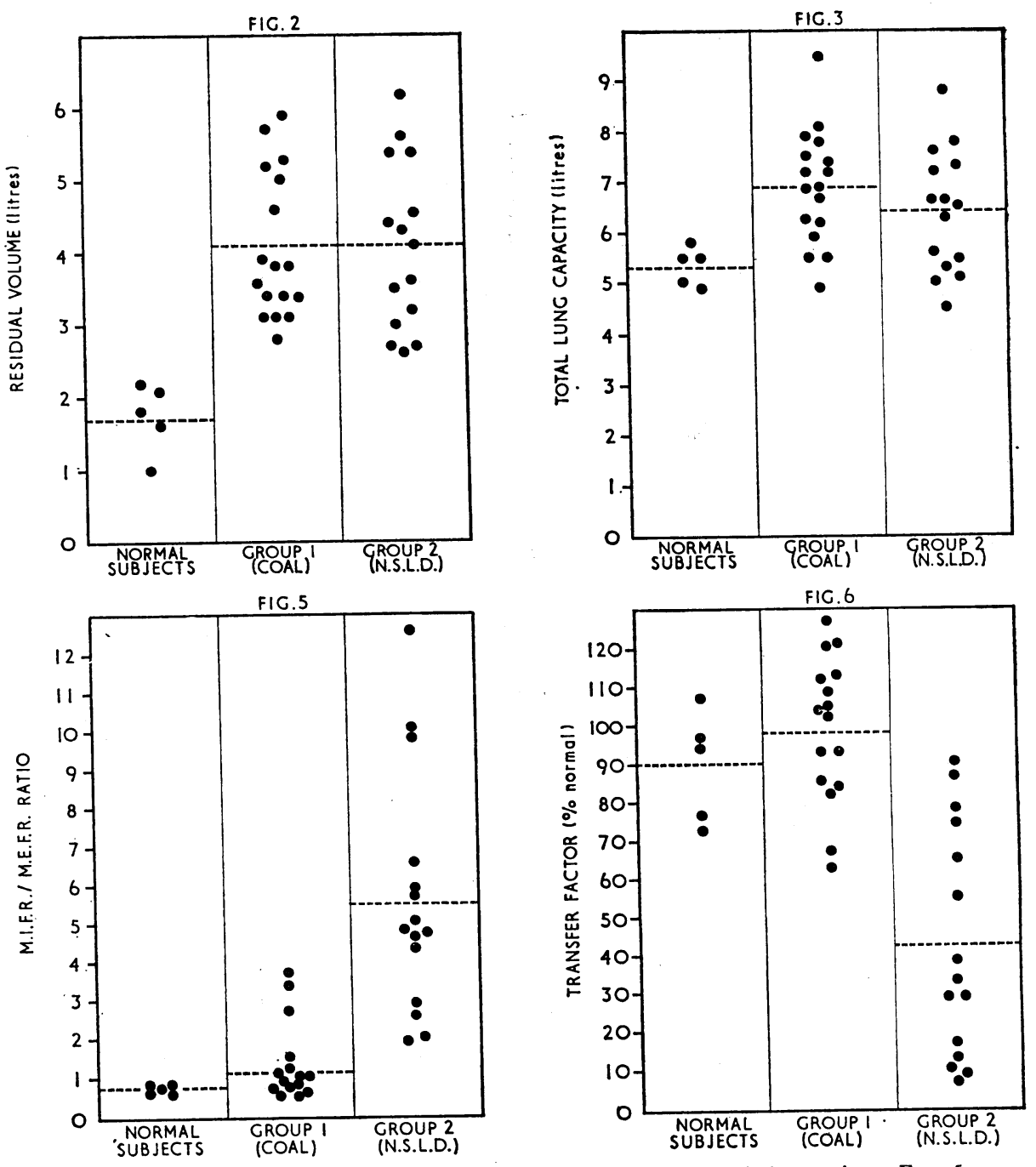

Mige. Fig. 3.-Total lung capacity. Fig. 4 -F.E.
M.I.F./M.E.F. ratio. FIG. 6.-Transfer factor. 
miners and were all free of symptoms, signs, and radiological evidence of respiratory disease.

\section{Results}

The vital statistics and physiological findings in the two groups are shown in Table II (miners) and Table III (nonspecific lung disease) and the results of the physiological tests are compared in Figs. 1 to 6 . The results obtained in the five normal subjects are recorded in Table IV and are also shown in Figs. 1 to 6.

Vital Statistics.-The mean age was 57 years (range 41-66) in the miners (group 1) and 58 years (range 50-70) in patients with chronic non-specific lung disease (group 2). The mean height was 67 in. $(170 \mathrm{~cm}$.) (range $63-72$ in.; $160-183 \mathrm{~cm}$.) and mean weight $151 \mathrm{lb}$. (68.4 kg.) (range 106-182 lb. ; 48$82.5 \mathrm{~kg}$.) in group 1, and $67 \mathrm{in}$. (170 cm.) (range 63-69 in.; 160-175 cm.) and $141 \mathrm{lb}$. (63.9 kg.) (range 109-187 lb. ; 49.4$84.8 \mathrm{~kg}$.) respectively in group 2.

Lung Volumes.-In Table V the mean values for V.C., R.V., and T.L.C. are expressed as the percentage of predicted normal according to the formula of Baldwin et al. (1948). Results are shown for the two groups in the present study and for the five normal subjects. According to the formula of Baldwin et al. and the findings in our own normal subjects, the residual volume is increased to about two and a half times the predicted normal in both groups, while the total lung capacity is increased by nearly one-third in the miners and by nearly one-quarter in the patients with non-specific lung disease (see also Figs. 2 and 3 ).

TABLB V.-Means of Lung Volume Fractions and M.V.V. Expressed as Percentage of Predicted Normal (By the Formulae of Baldwin et al., 1948)

\begin{tabular}{|c|c|c|c|c|}
\hline & & $\begin{array}{l}\text { Normal } \\
\text { Subjects }\end{array}$ & $\underset{\text { (Coal) }}{\text { Group } 1}$ & $\begin{array}{c}\text { Group 2 } \\
\text { (N.S.L.D.) }\end{array}$ \\
\hline $\begin{array}{l}\text { Vital capacity } \\
\begin{array}{l}\text { Residual volume } \\
\text { Total lung capacity }\end{array} \\
\text { Maximum voluntary ventilation }\end{array}$ & $\begin{array}{l}\cdots \\
\cdots \\
\cdots\end{array}$ & $\begin{array}{l}100 \% \\
106 \% \\
102 \% \\
106 \%\end{array}$ & $\begin{array}{r}78 \% \\
255 \% \\
132 \% \\
80 \%\end{array}$ & $\begin{array}{r}64 \% \\
256 \% \\
123 \% \\
41 \%\end{array}$ \\
\hline
\end{tabular}

Ventilatory Capacity.-The impairment of ventilatory capacity was considerably greater in group 2 than in group 1, the mean M.V.V. having nearly twice the value in the latter group (see Table V). This difference was due to the greater degree of expiratory airways obstruction in group $2:$ the mean M.I.F.R. was approximately the same in the two groups, but the mean M.E.F.R. in group 2 was less than one-quarter of the value obtained in group 1 . The values for the M.I.F.R./ M.E.F.R. ratio and for the F.E.V.. as percentage of vital capacity are compared for the two groups in Figs. 4 and 5 . It will be noted that in 12 of the miners but in none of the other group, the M.I.F.R./M.E.F.R. ratio was within the normal range (0.5-1.5). Eight miners, but none in the other group, showed a normal F.E.V.1 as percentage of V.C. (over $60 \%$ ).

Transfer Factor (Diffusing Capacity).-The mean transfer factor as percentage of predicted normal was $99 \%$ in group 1 and $42 \%$ in group 2 . Fourteen of the 16 miners had a normal transfer factor (over $75 \%$ ) as compared with 3 of the 15 patients in group 2 (see Fig. 6).

$\mathrm{PCO}_{2}$.-This was measured by the rebreathing method in seven patients from each group. The mean value for $\mathrm{PCO}_{2}$ in these patients was $36 \mathrm{~mm}$. $\mathrm{Hg}$ in group 1 and $43 \mathrm{~mm}$. $\mathrm{Hg}$ in group 2. The $\mathrm{PCO}_{2}$ was elevated in one patient from group 1 and in two patients from group 2.

\section{Discussion}

In any study of disability in coal miners the mode of selection is clearly important. In the present investigation the miners had all been referred by a general practitioner to a consultant physician and thence to a regional pulmonary function laboratory because physical and radiological examination had not revealed an adequate cause for their disability. Inevitably the question of eligibility for pension arose in a number of these patients, and in several the possibility of a "compensation neurosis" had been raised by the referring physician. It is not surprising, therefore, that more than half of these miners had no physical signs of bronchitis nor any radiological evidence of dust in the lungs and that only two (Cases 4 and 5) were in receipt of a pension for pneumoconiosis.

This group of miners had certain other features in common, less obviously related to the method of selection. Fifteen of the 17 were over the age of 50 and 12 had left the mines several years previous to the investigation. Twelve of the 17 had spent 30 years or more underground and, of the remaining five, two had been engaged in other forms of dusty work. Finally, they all showed an increase in residual volume, total lung capacity, and R.V./T.L.C.\% comparable to that observed in patients with chronic non-specific lung disease but without a commensurate degree of expiratory airways obstruction or impairment of the transfer factor.

Several authors (Gilson and Hugh-Jones, 1955 ; Carpenter et al., 1956 ; Higgins et al., 1956 ; Leathart, 1959) have found that miners with normal chest radiographs have a poorer M.V.V. than those whose films show simple pneumoconiosis. Furthermore, Gilson and Hugh-Jones (1955) reported a close correlation between M.V.V. and dyspnoea in coal miners, but when a group in hospital was studied the correlation between R.V./' T.L.C. $\%$ and dyspnoea was almost as good. In Fig. 7 M.V.V. has been plotted against R.V. for the miners in the present study and the grade of dyspnoea is indicated for each case. The eight

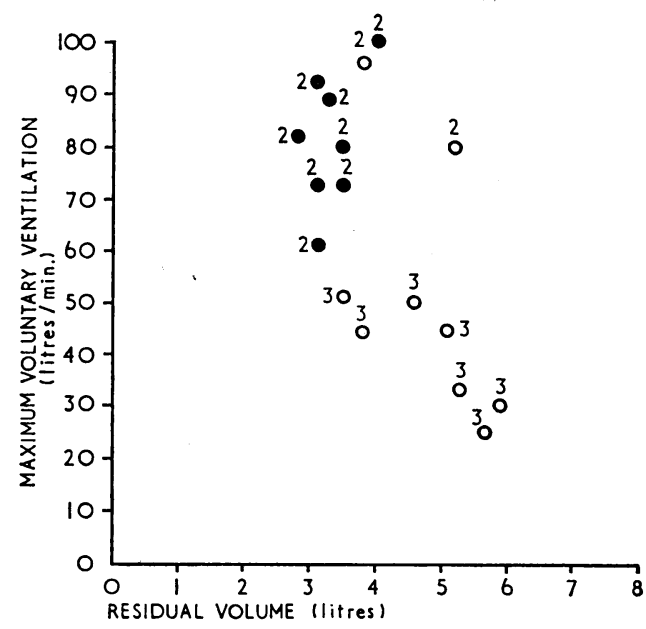

FIG. 7.-Relation between maximum voluntary vent:lation, residual volume, and dyspnoea. $Q=X$-ray evidence of pneumoconiosis. $\mathrm{O}=\mathrm{Clear}$ radiographs. (Figures indicate grade of dyspnoea.)

miners with simple pneumoconiosis tend to have a higher M.V.V. and smaller residual volume (mean M.V.V. $80 \mathrm{l} . / \mathrm{min}$. ; mean R.V. 3.31 .) than the miners with clear films (mean M.V.V. 50 1./min. ; mean R.V. 4.8 1.). Moreover, the grade of dyspnoea in these eight miners (grade 2) was less than in seven of the nine with clear films (grade 3 ). There appears, therefore, to be some relation between dyspnoea on the one hand and a low M.V.V. with increased residual volume on the other, but this relation is not necessarily a causal one, for there are many other variables of lung function which have not been measured in the present study. For example, uneven distribution of inspired gas (Gilson and Hugh-Jones, 1955), disturbances of the mechanical properties of the lungs (Leathart, 1959), and an increased alveolar-arterial $\mathrm{Po}_{2}$ difference (Brasseur, 1963) have all been reported in coal miners. 
Carpenter et al. (1956) have suggested that the lower values for M.V.V. found in miners with clear films than in those with simple pneumoconiosis might be due to generalized emphysema in the former group, and Leathart (1959) supported this view. The finding of an increased residual volume among such miners in the present study is also in keeping with this suggestion. A possible explanation for this paradox has been offered by Rappaport (1966), who suggested that emphysema could mask the shadows cast by dust in the lungs. If emphysema is the cause of the increased residual volume found among the miners in the present study, then its physiological manifestations differ from those reported by Fletcher et al. (1963) for patients with primary emphysema. Fletcher's patients showed an increase in residual volume and R.V./T.L.C.\% comparable to that found among the miners in the present series, but in addition there was severe airways obstruction and impairment of the transfer factor.

In their account of the pathogenesis of focal emphysema due to coal dust, Heppelston and Leopold (1961) pointed out that, initially, disruption of the alveoli is not a feature of this condition. Moreover, the bronchial smooth muscle is atrophic or absent and expiratory contraction of the bronchioles is diminished or abolished. Heppleston and Leopold attribute the alveolar dilatation to inspiratory traction upon the alveoli surrounding the deposits of dust rather than to expiratory airway obstruction. In the present investigation the finding among the coal miners of an increased residual volume with relatively less evidence of expiratory airway obstruction or impairment of gas transfer is compatible with Heppleston and Leopold's observations in focal emphysema. However, a normal transfer factor does not necessarily exclude alveolar destruction, and no conclusions can be drawn regarding the anatomical significance of our physiological findings. It is clear that a careful necropsy examination of the lungs of miners in whom physiological tests have been done during life is needed.

\section{Summary}

The physiological findings in 17 coal miners referred to a pulmonary function laboratory because of unexplained dyspnoea are compared with the findings in 15 patients referred with chronic non-specific lung disease and five normal subjects of the same age group.
The two groups of patients showed a comparable increase in residual volume, total lung capacity, and R.V./T.L.C.\%, but expiratory airways obstruction and impairment of gas transfer were considerably less in the group of miners than in the patients with chronic non-specific lung disease.

The increase in residual volume was greater in the miners with clear radiographs than in those with simple pneumoconiosis. The increase in residual volume was also greater in those with a reduced M.V.V. and a high grade of dyspnoea, but it could still be detected in breathless miners with a normal M.V.V. and no evidence of expiratory airways obstruction.

It is suggested that the physiological findings in this group of miners are compatible with some of the reported pathological features of focal emphysema due to coal dust, but no conclusions can be drawn until necropsy studies are available for miners investigated during life.

We are indebted to the technical staff of the regional pulmonary function laboratory, Broadgreen Hospital, for their assistance in carrying out the tests reported in this paper; to Dr. James Carmichael, who read the chest radiographs; and to the consultant physicians who referred the patients for investigation. We are especially grateful to Dr. James MacArthur for his help and encouragement.

\section{REFERENCES}

Baldwin, E. de F., Cournand, A., and Richards, D. W., jun. (1948), Medicine (Baltimore), 27, 243.

Brasseur, L. (1963). Lexploration fonctionnelle pulmonaire dans la pneumoconiose des houilleurs. Brussels.

Burrows, B., Niden, A. H., Fletcher, C. M., and Jones, N. L. (1964) Amer. Rev. resp. Dis., $90,14$.

Carpenter, R. G., Cochrane, A. L., Gilson, J. C., and Higgins, I. T. T (1956). Brit. F. industr. Med., 13, 166.

Ciba Guest Symposium (1959). Thorax, 14, 286. (1963). Quart. F. Med., 32, 33 .

Gilson, J. C., and Hugh-Jones, P. (1955). Spec. Rep. Ser. med. Res. Coun. (Lond.), No. 290

Heppleston, A. G., and Leopold, J. G. (1961). Amer. 7. Med., 31, 279.

Higgins, I. T. T., Oldham, P. D., Cochrane, A. L., and Gilson, J. C (1956). Brit. med. 7., 2, 904.

Leathart, G. L. (1959). Brit. F. industr. Med., 16, 153.

Ogilvie, C. M., Forster, R. E., Blakemore, W. S., and Morton, J. W. (1957) \%. clin. Invest., 36, 1.

Harris, L. H., Meecham, J., and Ryder, G. (1963). Brit. med. f., 1 , 1111.

Rappaport, I. (1966). Ibid., 1, 1356.

\title{
Psychiatric Study of a Consecutive Series of 34 Patients with Ulcerative Colitis*
}

\author{
FRED FELDMAN, M.D.; DAVID CANTOR, M.D. ; SIDNEY SOLL, M.D. ; WILLIAM BACHRACH, M.I)
}

Brit. med. F., 1967, 3, 14-17

The purpose of this study is to evaluate the role of psychiatric factors in the causation of ulcerative colitis by survey of a fairly long unselected series. Ulcerative colitis is still one of the most enigmatic of diseases, despite its position, paradoxically, as the " classic" psychosomatic illness. Its cause is believed by most gastroenterologists to be unknown, yet a large number of reports by psychiatrists discuss it as an unquestionably psychosomatic illness. The studies by physicians and surgeons of such medical factors as cause, course, complications, and drug treatment have been for the most part cautious, uncertain, and qualified (Crohn and Yarnis, 1951 ; Michener et al., 1961 ; Hijmans and Enzer, 1962 ; Korelitz et al., 1962 ; Edwards and Truelove, 1963,

* From the Department of Medicine and Department of Psychiatry, Cedars-Sinai Medical Center, Mount Sinai Division, Los Angeles, California.
1964 ; Rhodes and Kirsner, 1965). On the other hand, reports by psychiatrists of much smaller series (Engel, 1961 ; Finch and Hess, 1962 ; Fullerton et al., 1962 ; Powles, 1964), sometimes random and unselected, have used such terms as "constantly show severe psychopathology," "uniformly show pathology," " in every case," and "the evidence is overwhelming, incontrovertible."

We are aware that psychiatrists recognize that the disease is one which may be multifactorial in origin, and that some of them regard the psychogenic component as only one factor out of many. Nevertheless, the presence of severe psychopathic disease is so consistently described that the impression is gained from leading psychiatric papers that an emotional component is necessary for the condition to exist. Both sophisticated psychiatric readers and general physicians seem to derive this 